\title{
Activation of human lung mast cells by monomeric immunoglobulin $\mathrm{E}$
}

\author{
G. Cruse, D. Kaur, W. Yang, S.M. Duffy, C.E. Brightling and P. Bradding
}

\begin{abstract}
The mechanism of chronic mast cell activation in asthma is unclear. Monomeric immunoglobulin ( $\mathrm{Ig}) \mathrm{E}$ in the absence of allergen induces mediator release from rodent mast cells, indicating a possible role for IgE in the continued activation of mast cells within the asthmatic bronchial mucosa. In this study it was investigated whether monomeric IgE induces $\mathrm{Ca}^{2+}$ influx and mediator release from human lung mast cells (HLMC).

Purified HLMC were cultured for 4 weeks and then exposed to monomeric human myeloma IgE. Ratiometric $\mathrm{Ca}^{2+}$ imaging was performed on single fura-2-loaded cells. Histamine release was measured by radioenzymatic assay; leukotriene $\mathrm{C}_{4}\left(\mathrm{LTC}_{4}\right)$ and interleukin (IL)-8 were measured by ELISA.

At concentrations experienced in vivo, monomeric IgE induced dose-dependent histamine release, $\mathrm{LTC}_{4}$ production and IL-8 synthesis. This was associated with a rise in cytosolic free $\mathrm{Ca}^{2+}$. Enhanced histamine release was still evident 1 week after initial exposure to IgE suggesting that continued exposure maintains enhanced secretion.

Monomeric immunoglobulin $\mathrm{E}$ alone activates cultured human lung mast cells initiating $\mathrm{Ca}^{2+}$ influx, degranulation, arachidonic acid metabolism and cytokine synthesis. These findings support the hypothesis that immunoglobulin E loading of mast cells within the asthmatic airway contributes to the disordered airway physiology of this disease.
\end{abstract}

KEYWORDS: Asthma, calcium, human, mast cell, mediators, monomeric immunoglobulin E

$\mathbf{M}$ ast cells play a central role in the immunopathology of asthma through the sustained secretion of a plethora of proinflammatory mediators, cytokines and proteases (reviewed in [1]). They infiltrate key structures in asthmatic airways, such as the airway smooth muscle (ASM) [2] and airway mucous glands [3], events that are likely to be critical for the targeting of mediators to their intended site of action.

It is often assumed that chronic mast cell activation in asthma is driven by exposure of the airways to inhaled aeroallergens, resulting in cross-linking of allergen-specific immunoglobulin (Ig)E bound to the mast cell high affinity $\mathrm{IgE}$ receptor FceRI. However, allergen avoidance usually has only a minor effect on the state of established asthma, which appears to become "self-perpetuating" [4]. Mast cell hypersecretion in on-going asthma may therefore arise from alternative stimuli, for example by proteases [5], adenosine [6], and by cytokines, such as stem cell factor (SCF) [7]. Of great interest, monomeric $\operatorname{IgE}$ alone can induce mediator release from the rat mast cell line RBL-2H3 and mouse bone marrowderived mast cells (BMMC) in the absence of $\operatorname{IgE}$ cross-linking by antigen $[8,9]$. In addition, IgE prolongs rodent mast cell survival, in part through the autocrine release of survivalenhancing cytokines, such as interleukin (IL)-6 [8]. For reasons that are unknown, the extent of these responses depends on the source of the $\mathrm{IgE}$. Thus, some types of IgE induce both histamine and cytokine synthesis, while others induce the release of cytokines only [8]. These observations are particularly interesting because in humans there is a reproducible correlation between total serum IgE concentration, bronchial hyperresponsiveness and asthma [10-13]. Thus, it is attractive to hypothesise that in asthma, heightened mast cell activation within the airways arises, at least in part, from the increased binding of $\operatorname{IgE}$ to FceRI.

The effects of monomeric IgE on human lung mast cell (HLMC) function are unknown. There are important functional differences between rodent and human mast cells, which are typified by the marked differences in ion channel activity the current authors have recently demonstrated [14]. Therefore, ultimately, studies must be performed on human cells and from the tissue of interest. In this study, the present authors have

\section{AFFILIATIONS}

Institute for Lung Health, Dept of

Infection, Immunity and

Inflammation, University of Leicester and Warwick Medical School, University Hospitals of Leicester, Glenfield General Hospital, Leicester, UK.

\section{CORRESPONDENCE}

P. Bradding

Dept of Respiratory Medicine

Glenfield Hospital

Groby Rd

Leicester

LE3 9QP

UK

Fax: 441162502787

E-mail: pbradding@hotmail.com

Received:

August 032004

Accepted after revision:

January 202005

SUPPORT STATEMENT

This study was supported by Asthma UK.

Online ISSN 1399-3003 
taken the first step in testing their hypothesis. They demonstrate that $\mathrm{IgE}$, in the absence of cross-linking by allergen, activates cultured HLMC resulting in $\mathrm{Ca}^{2+}$ influx and the release of histamine, leukotriene $\mathrm{C}_{4}\left(\mathrm{LTC}_{4}\right)$ and $\mathrm{IL}-8$. This has important implications for the pathogenesis of asthma.

\section{METHODS}

\section{HLMC purification and culture}

All human subjects gave written informed consent and the study was approved by the Leicestershire Research Ethics Committee, UK. HLMC were dispersed and purified from macroscopically normal lung obtained within $1 \mathrm{~h}$ of resection for lung cancer using immunoaffinity magnetic selection as described previously [15]. The final HLMC purity was $>98 \%$ with cell viability $>97 \%$ (monitored by exclusion of trypan blue). Following isolation, HLMC were cultured in Dulbecco's modified essential medium (DMEM)/Glutamax/HEPES containing 10\% FBS, 1\% MEM nonessential amino acids (all from Life Technologies, Paisley, UK), 1\% antibiotic/antimycotic solution (Sigma, Poole, UK), $100 \mathrm{ng} \cdot \mathrm{mL}^{-1}$ recombinant human (rh)SCF, $50 \mathrm{ng} \cdot \mathrm{mL}^{-1} \mathrm{rhIL}-6$ and $10 \mathrm{ng} \cdot \mathrm{mL}^{-1} \mathrm{rhIL}-10 \quad(\mathrm{R} \& \mathrm{D}$, Abington, $\mathrm{UK}$ ) at $37^{\circ} \mathrm{C}$ in a humidified incubator flushed with $5 \% \mathrm{CO}_{2}$ for a minimum of 4 weeks prior to experiments [16]. Half of the medium was changed every 7 days.

\section{$\mathrm{Ca}^{2+}$ imaging}

Changes in cytosolic-free $\mathrm{Ca}^{2+}\left(\left[\mathrm{Ca}^{2+}\right]_{\mathrm{i}}\right)$ were monitored fluorometrically by use of the $\mathrm{Ca}^{2+}$-sensitive probe Fura- 2 as described previously [16]. Data acquisition occurred at a rate of one dual-wavelength image every $6 \mathrm{~s}$ as the $340 / 380 \mathrm{nM}$ ratio. This was converted to $\left[\mathrm{Ca}^{2+}\right]_{\mathrm{i}}$ using a commercially available calibration kit (Molecular probes). IgE was added to the dish as required.

\section{HLMC activation for mediator release}

Mast cells $\left(1 \times 10^{4}\right)$ were warmed to $37^{\circ} \mathrm{C}$ in triplicate in $50 \mu \mathrm{L}$ of DMEM and $50 \mu \mathrm{L}$ monomeric human myeloma $\operatorname{IgE}$ (Calbiochem-Novabiochem, Nottingham, UK), or human IgG (Sigma, Poole, Dorset), at $2 \times$ the final concentration was then added. After incubation for $30 \mathrm{~min}$ or $24 \mathrm{~h}$ at $37^{\circ} \mathrm{C}$, the cells were centrifuged at $250 \times g$ for $4 \mathrm{~min}$, and the supernatant decanted. Control cell pellets were lysed in sterile deionised water for measurement of total histamine content.

To investigate whether there were any aggregates of $\operatorname{IgE}$ present in the $\operatorname{IgE}$ preparation, freshly constituted $\operatorname{IgE}$ was centrifuged at $14000 \times g$ for $20 \mathrm{~min}$, the supernatant removed and any aggregates resuspended in PBS. A dose-response of centrifuged $\operatorname{IgE}$, any aggregated $\operatorname{IgE}$ and the normal $\operatorname{IgE}$ was then run in parallel.

\section{Mediator assays}

Histamine was measured by radioenzymatic assay, as described previously [15]. LTC $_{4}$ (Cayman Chemical Co., Ann Arbor, MI, USA) and IL-8 (BD Biosciences, San Diego, CA, USA) were measured by ELISA according to the manufacturer's instructions.

\section{Data presentation and statistical analysis}

Data is expressed as the mean \pm SEM unless otherwise stated. Histamine, $\mathrm{LTC}_{4}$ and IL- 8 are expressed in $\mathrm{ng} \cdot 10^{-6}$ cells released into supernatants. Differences between groups of data were evaluated using paired or unpaired (two tailed) t-test as appropriate. A p-value of $<0.05$ was considered statistically significant.

\section{RESULTS}

\section{Monomeric IgE induces the release of histamine, $\mathrm{LTC}_{4}$ and} IL-8 from HLMC

Since SCF is an essential growth factor for human mast cells, withdrawal of which induces apoptosis, and which is present even in normal tissues but elevated in asthmatic airways [17], the effect of monomeric IgE on HLMC incubated in their normal SCF-supplemented growth medium was first examined. The early release (30 $\mathrm{min}$ ) of pre-formed granule-derived histamine and the newly synthesised product of arachidonic acid metabolism $\mathrm{LTC}_{4}$, in addition to the late $(24 \mathrm{~h})$ release of the chemokine IL-8, was studied. Interestingly, the current authors found that HLMC from several separate donors released histamine and $\mathrm{LTC}_{4}$ in a dose-dependent manner when incubated with $\operatorname{IgE}$ for $30 \mathrm{~min}$ in the presence of SCF (fig. $1 \mathrm{a}$ and b). Thus, control histamine release was $258 \pm 26 \mathrm{ng} \cdot 10^{-6}$ cells compared with $583 \pm 99 \mathrm{ng} \cdot 10^{-6}$ cells with the addition of $3 \mu \mathrm{g} \cdot \mathrm{mL}^{-1} \mathrm{IgE}$, giving a net monomeric $\mathrm{IgE}$ dependent histamine release of $325 \pm 88 \mathrm{ng} \cdot 10^{-6}$ cells $(12.8 \%$ of cell total $)(p=0.008, n=8$; fig. 1 a). There was a parallel increase in the release of $\mathrm{LTC}_{4}$ with net monomeric IgE-dependent release of $4.3 \pm 1.2 \mathrm{ng} \cdot 10^{-6}$ cells at a concentration of $3 \mu \mathrm{g} \cdot \mathrm{mL}^{-1}$ $\operatorname{IgE}(p=0.038, n=4$; fig. 1 b). IL-8 concentrations were measured after $24 \mathrm{~h}$ in cells activated with $3 \mu \mathrm{g} \cdot \mathrm{mL}^{-1} \mathrm{IgE}$ and were significantly elevated compared with control (control $2.77 \pm 0.51 \mathrm{ng} \cdot 10^{-6}$ cells, IgE $7.33 \pm 0.19 \mathrm{ng} \cdot 10^{-6}$ cells, $\mathrm{p}=0.003$, $\mathrm{n}=4$; fig. $1 \mathrm{c}$ ). To see if this effect was IgE specific, a parallel test was run using $\operatorname{IgG}$ and there was found to be no release of histamine in these cells $\left(299 \pm 27 \mathrm{ng} \cdot 10^{-6}\right.$ cells in the control cells, compared with $273 \pm 42 \mathrm{ng} \cdot 10^{-6}$ cells with the addition of $\left.3 \mu \mathrm{g} \cdot \mathrm{mL}^{-1} \operatorname{IgG}, \mathrm{p}=0.37, \mathrm{n}=4\right)$.

In vivo, serum $\operatorname{IgE}$ concentrations remain fairly stable, so it was important to assess whether the effects of monomeric IgE were sustained. In three further donors, HLMC were cultured with or without $3 \mu \mathrm{g} \cdot \mathrm{mL}^{-1} \mathrm{IgE}$ for 7 days in their normal SCFsupplemented growth medium before washing to remove accumulated histamine and resuspending in medium $\pm \operatorname{IgE}$. Histamine release was $125 \pm 27 \mathrm{ng} \cdot 10^{-6}$ cells without $\mathrm{IgE}$ compared with $1033 \pm 480 \mathrm{ng} \cdot 10^{-6}$ cells in the presence of $3 \mu \mathrm{g} \cdot \mathrm{mL}^{-1}$ IgE, giving a net histamine release of $909 \pm 288 \mathrm{ng} \cdot 10^{-6}$ cells $(24.6 \%$ of cell total $)(n=3, p=0.05)$. This suggests that $\operatorname{IgE}$ signalling is maintained when FceRI are occupied.

Although less physiological, most studies investigating human mast cell histamine release have done so in the absence of SCF. When HLMC were activated with monomeric IgE in the absence of SCF this also resulted in acute histamine release in 12 of 14 donors, although this was significantly lower than in the experiments in the presence of SCF. Thus, with $3 \mu \mathrm{g} \cdot \mathrm{mL}^{-1}$ monomeric IgE, histamine release increased from $162 \pm 51 \mathrm{ng} \cdot 10^{-6}$ cells to $213 \pm 59 \mathrm{ng} \cdot 10^{-6}$ cells, giving a net histamine release of $51 \pm 10 \mathrm{ng} \cdot 10^{-6}$ cells ( $1.7 \%$ of cell total) (all 14 donors, $p=0.0002)$. This histamine release was also found to be accompanied by arachidonic acid metabolism even in SCFdeprived cells, exemplified by the release of $\mathrm{LTC}_{4}$ in the $\mathrm{IgE}$ treated cells, rising from $175 \pm 28 \mathrm{pg} \cdot 10^{-6}$ cells in the control 

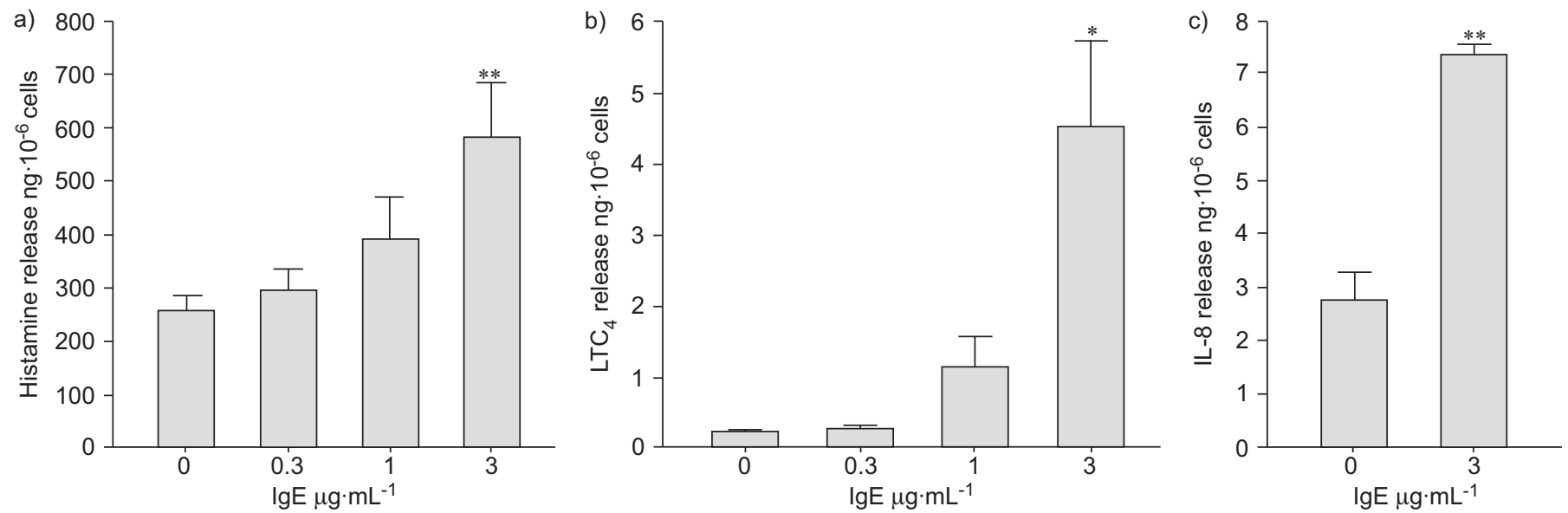

FIGURE 1. The activation of human lung mast cells by monomeric immunoglobulin (lg)E in the presence of stem cell factor $100 \mathrm{ng} \cdot \mathrm{mL}^{-1}$. IgE alone induces the dosedependent release of a) the pre-formed granule-derived mediator histamine $(n=8), b)$ the de novo synthesised arachidonic acid metabolite leukotriene $\mathrm{C}_{4}\left(\mathrm{LTC}_{4} ; \mathrm{n}=4\right)$, and c) newly synthesised interleukin (IL)-8 ( $n=4)$. All values are mean \pm SEM. *: $p<0.05$; **: $p<0.01$.

cells to $348 \pm 76 \mathrm{pg} \cdot 10^{-6}$ in the $3 \mu \mathrm{g} \cdot \mathrm{mL}^{-1}$ IgE-treated cells $(\mathrm{p}=0.046, \mathrm{n}=10)$ (net release of $172 \pm 75 \mathrm{pg} \cdot 10^{-6}$ cells).

The activation of mast cells by IgE alone often raises the question of whether the $\mathrm{IgE}$ used is truly monomeric. It is conceivable that the effects reported are caused by low level aggregates of $\mathrm{IgE}$ in the preparations, which when added to the cells cross-link $F_{c \varepsilon R I}$, thus mimicking allergen exposure. To address this, freshly constituted IgE was centrifuged at $14000 \times g$ for $20 \mathrm{~min}$, the supernatant removed and any potential aggregates resuspended in PBS. A dose-response of centrifuged $\operatorname{IgE}$ was then run, with any aggregated $\operatorname{IgE}$ and the normal IgE in parallel, and there was found to be no significant difference between the centrifuged and normal $\mathrm{IgE}$ (net histamine release of $51 \pm 7 \mathrm{ng} \cdot 10^{-6}$ cells and $57 \pm 8 \mathrm{ng} \cdot 10^{-6}$ cells, respectively with $3 \mu \mathrm{g} \cdot \mathrm{mL}^{-1} \mathrm{IgE}$ ). In addition, if any aggregates were in the precipitate, they did not elicit any response in the cells (net histamine release $5 \pm 2 \mathrm{ng} \cdot 10^{-6}$ cells), which is consistent with the previous observations by KALESNIKOFF et al. [18].

\section{Monomeric IgE increases cytosolic-free $\mathrm{Ca}^{2+}$}

Next to be investigated was whether monomeric IgEdependent histamine release from HLMC was associated with a rise in $\left[\mathrm{Ca}^{2+}\right]_{\mathrm{i}}$. It was found that in the absence of SCF, monomeric IgE induced a significant increase in $\left[\mathrm{Ca}^{2+}\right]_{i}$ from a basal level of $277.4 \pm 4.7 \mathrm{nM} 3 \mathrm{~min}$ prior to the addition of $\mathrm{IgE}$ to $376.2 \pm 8.39 \mathrm{nM} 2 \mathrm{~min}$ following the addition of $3 \mu \mathrm{g} \cdot \mathrm{mL}^{-1}$ $\operatorname{IgE}(\mathrm{p}=0.0001, \mathrm{n}=162$ cells from four separate donors; fig. 2 ). The current authors have recently shown that there is a tight correlation in HLMC between change in $\left[\mathrm{Ca}^{2+}\right]_{i}$ and the magnitude of anti-IgE-dependent histamine release [19]. From this relationship, the change in $\left[\mathrm{Ca}^{2+}\right]_{i}$ in the present study would predict a net histamine release of $\sim 3 \%$ of the cell total, which is very close to that actually measured $(2.0 \%$ excluding nonresponders). The $\mathrm{Ca}^{2+}$ plateau was relatively smooth, in keeping with the changes reported in HLMC after anti-IgE-dependent activation, although occasional cells exhibited oscillations similar to those described previously in basophils [20]. This suggests that the signalling pathways activated by monomeric IgE and anti-IgE may be similar, in keeping with the recent conclusions from rodent studies [21].

\section{DISCUSSION}

This study makes the novel observation that cultured HLMC release histamine, $\mathrm{LTC}_{4}$ and IL-8 on acute exposure to monomeric $\operatorname{IgE}$ and that this effect is maintained while $\operatorname{IgE}$ remains present. The effects are relatively small compared with anti-IgE-dependent activation, particularly in the absence of SCF, but even this magnitude of mediator release may be of great physiological significance where mast cells infiltrate key tissue structures.

Many in vitro studies on mast cells have relied on maximally activating the cells with FcERI cross-linking, leading to anaphylactic degranulation and massive histamine release. However, this level of maximal cell activation is of questionable physiological relevance because it is probably never achieved in humans in vivo, except perhaps during anaphylaxis and laboratory allergen challenge. Certainly in chronic on-going asthma, mast cell activation is far less aggressive, with piecemeal degranulation evident on electron microscopy rather than the anaphylactic degranulation that occurs with maximal cell activation [22]. There are also significantly lower concentrations of mediators present in bronchoalveolar lavage fluid in stable asthma compared with post-allergen challenge [23]. Thus, the relatively subtle release of mediators demonstrated with monomeric IgE may be important when there is close approximation of target cells. This is particularly relevant in asthma where there is microlocalisation of mast cells within specific tissue structures, such as the ASM [2]. The observation that HLMC not only degranulate but also metabolise arachidonic acid and synthesise cytokines in response to IgE suggests that several diverse tissue effects will ensue. For example, histamine is a bronchoconstrictor, tryptase is an ASM mitogen [24], cysteinyl leukotrienes are potent bronchoconstrictors and potentiate ASM proliferation following exposure to IL-13 [25], while IL-8 is also a potent smooth muscle mitogen [26]. Furthermore, since concentrations of SCF are elevated in asthmatic airways [17], and SCF is a product of ASM [27], it 

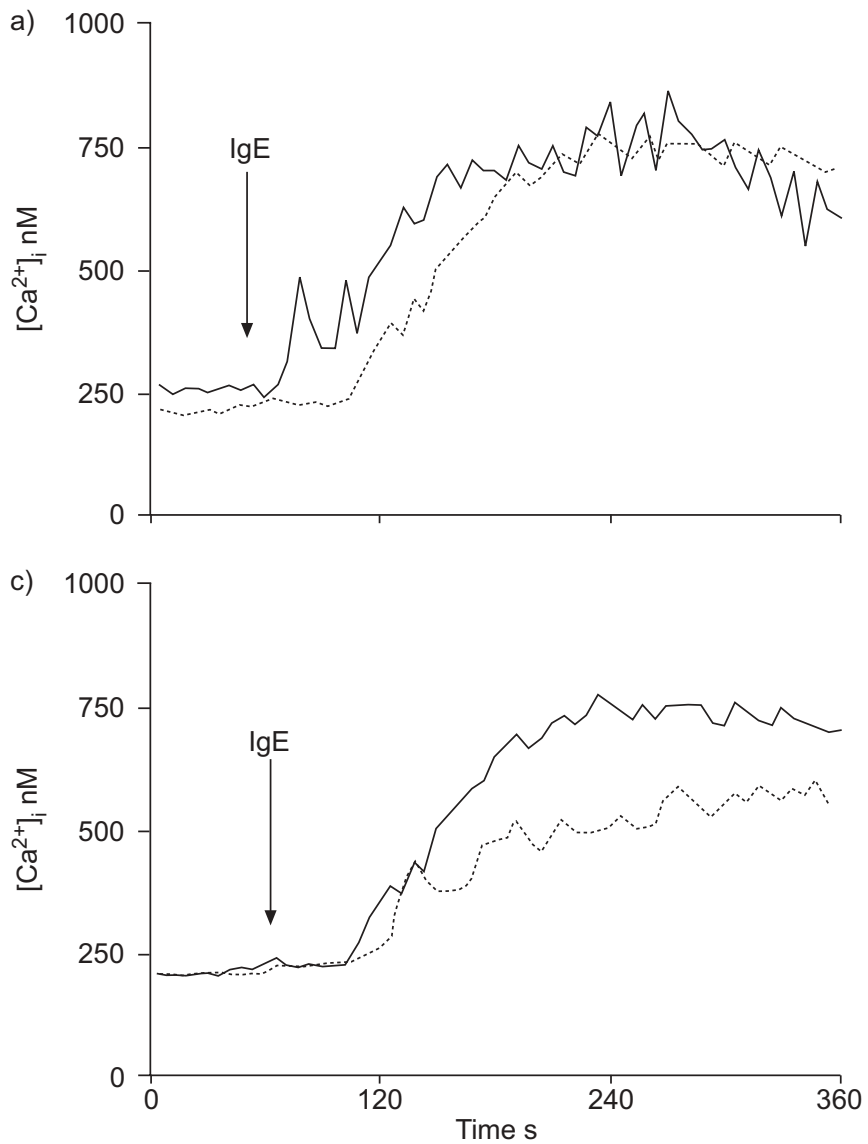

b)

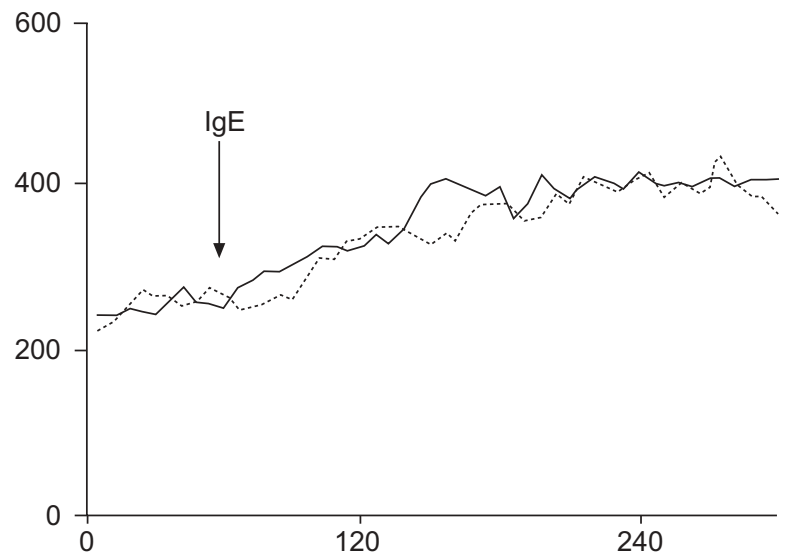

d)

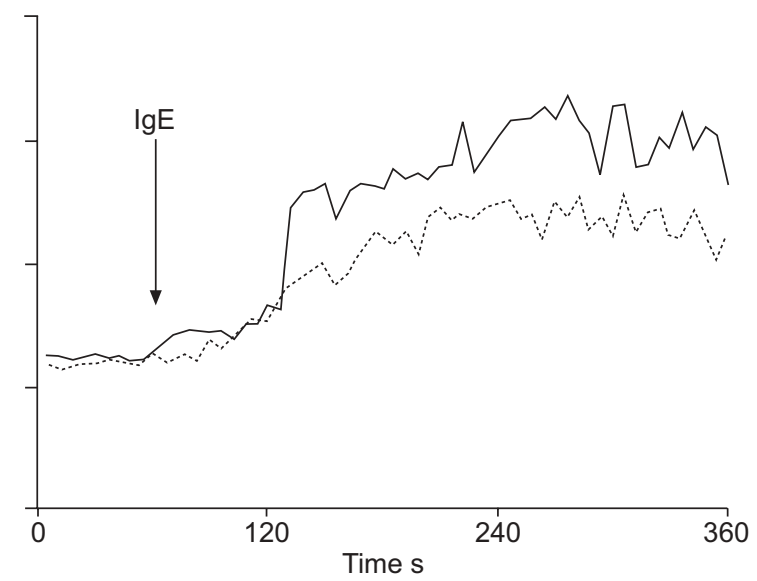

FIGURE 2. Heterogeneity of changes in $\left[\mathrm{Ca}^{2+}\right]_{i}$ in human lung mast cells during incubation with $3 \mu \mathrm{g} \cdot \mathrm{mL}^{-1}$ monomeric immunoglobulin (lg)E. Each panel represents a different donor and each trace an individual cell.

is easy to envisage a positive feedback loop whereby monomeric IgE together with ASM-derived SCF activates mast cells, which in turn activate ASM. Such a pathway of mast cell activation in asthma would help explain the strong correlation evident between total rather than specific serum $\operatorname{IgE}$ and the degree of bronchial hyperresponsiveness [10-13].

Serum concentrations of IgE remain relatively constant over time, so it is important that the current authors have shown that 1 week after exposure to $\mathrm{IgE}$, the potentiated HLMC secretory response is maintained. This is consistent with the data from RBL-2H3 cells, showing that cell signalling continues as long as unbound IgE is present. Removal of "free" IgE quickly returns the cells to quiescence. Reintroduction of $\mathrm{IgE}$ to the sensitised cells promptly recommences signalling, suggesting that bound IgE does not prevent "free" IgE signalling [21]. These observations, therefore, provide a further mechanism for the enhanced constitutive mediator release evident in mast cells obtained from asthmatic versus normal subjects [28]. It is also of note that the top concentration of $\mathrm{IgE}$ studied, $3 \mu \mathrm{g} \cdot \mathrm{mL}^{-1}$, is equivalent to $\sim 1250 \mathrm{iU} \cdot \mathrm{mL}^{-1}$, well within the range experienced in vivo.

In this study lung mast cells that have been maintained in culture for at least 4 weeks have been used, as described recently by the current authors [16]. This was for several reasons. First, freshly isolated mast cells from normal donors are relatively quiescent compared with those from asthmatic subjects, and a large proportion of the cells do not express FceRI $[28,29]$. Those that do express FceRI are likely to have them occupied by endogenous $\operatorname{IgE}$, which would require stripping at low $\mathrm{pH}$, resulting in cell damage. In contrast, the cultured cells all express FceRI, and when sensitised with IgE release greater quantities of mediators in response to anti-IgE than freshly isolated cells $[16,19]$. More importantly, about half the cells die within the first week of culture, but then proliferate, so that by 4 weeks there are up to five times the starting number [16]. Thus, $\geqslant 90 \%$ of the cells at 4 weeks will never have been exposed to $\mathrm{IgE}$, making the experiments viable. Also, since there is a clearly increased expression of SCF in asthmatic compared with normal airways [17], these cells that have been cultured in SCF may also be more representative of the asthmatic phenotype than those from normal subjects.

When examining the effects of IgE on HLMC activation, it is important to ensure that the IgE used is indeed monomeric. $\operatorname{IgE}$ preparations were therefore centrifuged and a doseresponse of centrifuged $\operatorname{IgE}$, uncentrifuged $\operatorname{IgE}$ and any aggregated $\operatorname{IgE}$ was ran in parallel and there was found to be no significant difference between the centrifuged and uncentrifuged preparations. This is consistent with the observation by KALESNIKOFF et al. [18], that although the IgE used in their experiments (SPE-7 anti-dinitrophenol) contained aggregates, 
the aggregates themselves were considerably less effective at eliciting a response than monomeric IgE [18].

Previous work from the mouse and RBL-2H3 cells suggests that the mechanism by which monomeric IgE results in mast cell activation is through enhanced dimerisation of FceRI [18, 21]. This would suggest that the signalling pathway activated should be similar to that activated by anti-IgE. In terms of $\mathrm{Ca}^{2+}$ mobilisation, in previous murine studies $\operatorname{IgE}$ alone has been reported to cause $\mathrm{Ca}^{2+}$ mobilisation leading to a rise in $\left[\mathrm{Ca}^{2+}\right]_{\mathrm{i}}$, but which fails to reach the threshold necessary for degranulation to occur. Studies by HUBER et al. [30] and KALESNIKOFF et al. [18] found that the degranulatory response to $\operatorname{IgE}$ alone in wild-type BMMC was not significant despite an increase in $\left[\mathrm{Ca}^{2+}\right]_{\mathrm{i}}$ and evidence that both $\beta$ and $\gamma$ subunits of FceRI, along with many Erk kinases and SH2-containing inositol 5'phosphatase, were tyrosine phosphorylated [18]. Another study by OKA et al. [9] reports that the addition of monomeric IgE to RBL-2H3 cells induced a significant increase in both $\left[\mathrm{Ca}^{2+}\right]_{\mathrm{i}}$ and mediator release. However, in the same study, murine BMMC exhibited markedly less (but still significant) degranulation than RBL-2H3 cells, despite the $\left[\mathrm{Ca}^{2+}\right]_{i}$ increase being comparable [9]. It has been shown that the $\mathrm{Ca}^{2+}$ signals observed in HLMC were similar to those described previously by the current authors and others, following anti-IgEdependent cell activation [19, 20]. This suggests that the signalling pathways activated by anti-IgE and monomeric $\operatorname{IgE}$ share several components, but whether these are identical will require further study.

Interestingly, in contradiction to the current authors' results, the only previous study of monomeric $\operatorname{IgE}$ on human mast cell activation used cord-blood-derived mast cells and reported no significant effect on histamine or IL-8 release, although this was in the absence of SCF [31]. It is well recognised that there is marked heterogeneity in mast cell responses both between species and from different tissues within the same species, so the data again highlights the importance of studying cells from the tissue of interest.

In conclusion, the results indicate that monomeric immunoglobulin $\mathrm{E}$ alone induces the release of histamine, leukotriene $\mathrm{C}_{4}$ and interleukin-8 from human lung mast cells. The magnitude of release is less than the massive release that can be obtained with anti-immunoglobulin E or allergen, but this may actually be more physiologically relevant. Since mast cells infiltrate key airways structures, such as the airway smooth muscle in asthma, the diverse array of mediators secreted in response to monomeric immunoglobulin $\mathrm{E}$ may have critical consequences for the function of these cells. These findings would help explain the strong correlations observed between total serum immunoglobulin $\mathrm{E}$ and the presence of asthma and bronchial hyperresponsiveness, and the ability of antiimmunoglobulin $\mathrm{E}$ treatment to ameliorate the disease in contrast to allergen avoidance [32]. The ability of monomeric immunoglobulin E to activate human lung mast cells could, therefore, be central to the chronic symptoms of established asthma.

\section{ACKNOWLEDGEMENTS}

The authors would like to thank S. Harper (AstraZeneca R\&D Charnwood, Loughborough, UK) for the generous gift of the rat kidney histamine methyl transferase used in the histamine assays, and D. Parker and L. Woodman for their technical assistance.

\section{REFERENCES}

1 Bradding $\mathrm{P}$. The role of the mast cell in asthma: a reassessment. Curr Opin Allergy Clin Immunol 2003; 3: 45-50.

2 Brightling CE, Bradding P, Symon FA, et al. Mast cell infiltration of airway smooth muscle in asthma. N Engl J Med 2002; 346: 1699-1705.

3 Carroll NG, Mutavdzic S, James AL. Increased mast cells and neutrophils in submucosal mucous glands and mucus plugging in patients with asthma. Thorax 2002; 57: 677-682.

4 Woodcock A, Forster L, Matthews E, et al. Control of exposure to mite allergen and allergen-impermeable bed covers for adults with asthma. N Engl J Med 2003; 349: 225-236.

5 Machado DC, Horton D, Harrop R, et al. Potential allergens stimulate the release of mediators of the allergic response from cells of mast cell lineage in the absence of sensitization with antigen-specific IgE. Eur J Immunol 1996; 26: 2972-2980.

6 Polosa $\mathrm{R}, \mathrm{Ng} \mathrm{WH}$, Crimi $\mathrm{N}$, et al. Release of mast-cellderived mediators after endobronchial adenosine challenge in asthma. Am J Respir Crit Care Med 1995; 151: 624-629.

7 Frenz AM, Gibbs BF, Pearce FL. The effect of recombinant stem cell factor on human skin and lung mast cells and basophil leukocytes. Inflamm Res 1997; 46: 35-39.

8 Kitaura J, Song J, Tsai M, et al. Evidence that IgE molecules mediate a spectrum of effects on mast cell survival and activation via aggregation of the FceRI. PNAS 2003; 100: 12911-12916.

9 Oka T, Hori M, Tanaka A, et al. IgE alone-induced actin assembly modifies calcium signaling and degranulation in RBL-2H3 mast cells. Am J Physiol Cell Physiol 2004; 286: C256-C263.

10 Burrows B, Martinez FD, Halonen M, et al. Association of asthma with serum IgE levels and skin-test reactivity to allergens. N Engl J Med 1989; 320: 271-277.

11 Sears MR, Burrows B, Flannery EM, et al. Relation between airway responsiveness and serum $\operatorname{IgE}$ in children with asthma and in apparently normal children. $N$ Eng J Med 1991; 325: 1067-1071.

12 Sunyer J, Anto JM, Sabria J, et al. Relationship between serum $\operatorname{IgE}$ and airway responsiveness in adults with asthma. J Allergy Clin Immunol 1995; 95: 699-706.

13 Sunyer J, Anto JM, Castellsague J, et al. Total serum IgE is associated with asthma independently of specific IgE levels. The Spanish Group of the European Study of Asthma. Eur Respir J 1996; 9: 1880-1884.

14 Duffy SM, Lawley WJ, Conley EC, et al. Resting and activation-dependent ion channels in human mast cells. J Immunol 2001; 167: 4261-4270.

15 Sanmugalingam D, Wardlaw AJ, Bradding P. Adhesion of human lung mast cells to bronchial epithelium: evidence for a novel carbohydrate-mediated mechanism. J Leuk Biol 2000; 68: 38-46.

16 Duffy SM, Lawley WJ, Kaur D, et al. Inhibition of human mast cell proliferation and survival by tamoxifen in 
association with ion channel modulation. I Allergy Clin Immunol 2003; 112: 970-977.

17 Al-Muhsen SZ, Shablovsky G, Olivenstein R, et al. The expression of stem cell factor and c-kit receptor in human asthmatic airways. Clin Exp Allergy 2004; 34: 911-916.

18 Kalesnikoff J, Huber M, Lam V, et al. Monomeric $\operatorname{IgE}$ stimulates signaling pathways in mast cells that lead to cytokine production and cell survival. Immunity 2001; 14 801-811.

19 Duffy SM, Berger P, Cruse G, et al. The $\mathrm{K}^{+}$channel $\mathrm{iK}_{\mathrm{CA}} 1$ potentiates $\mathrm{Ca}^{2+}$ influx and degranulation in human lung mast cells. J Allergy Clin Immunol 2004; 114: 66-72.

20 MacGlashan DJ, Guo CB. Oscillations in free cytosolic calcium during IgE-mediated stimulation distinguish human basophils from human mast cells. J Immunol 1991; 147: 2259-2269.

21 Pandey V, Mihara S, Fensome-Green A, et al. Monomeric IgE stimulates NFAT translocation into the nucleus, a rise in cytosol $\mathrm{Ca} 2+$, degranulation, and membrane ruffling in the cultured rat basophilic leukemia-2H3 mast cell line. J Immunol 2004; 172: 4048-4058.

22 Djukanovic R, Lai CK, Wilson JW, et al. Bronchial mucosal manifestations of atopy: a comparison of markers of inflammation between atopic asthmatics, atopic nonasthmatics and healthy controls. Eur Respir J 1992; 5: 538-544.

23 Wenzel SE, Westcott JY, Larsen GL. Bronchoalveolar lavage fluid mediator levels 5 minutes after allergen challenge in atopic subjects with asthma: relationship to the development of late asthmatic responses. J Allergy Clin Immunol 1991; 87: 540-548.

24 Brown JK, Jones CA, Rooney LA, et al. Tryptase's potent mitogenic effects in human airway smooth muscle cells are via nonproteolytic actions. Am J Physiol 2002; 282 L197-L206.

25 Espinosa K, Bosse Y, Stankova J, et al. CysLT1 receptor upregulation by TGF- $\beta$ and IL-13 is associated with bronchial smooth muscle cell proliferation in response to LTD4. J Allergy Clin Immunol 2003; 111: 1032-1040.

26 Yue TL, Wang X, Sung CP, et al. Interleukin 8. A mitogen and chemoattractant for vascular smooth muscle cells. Circ Res 1994; 72: 1-7.

27 Kassel O, Schmidlin F, Duvernelle C, et al. Human bronchial smooth muscle cells in culture produce stem cell factor. Eur Respir J 1999; 13: 951-954.

28 Flint KC, Leung KB, Hudspith BN, et al. Bronchoalveolar mast cells in extrinsic asthma: a mechanism for the initiation of antigen specific bronchoconstriction. BMJ 1985; 291: 923-926.

29 Humbert M, Grant JA, Taborda-Barata L, et al. Highaffinity $\operatorname{IgE}$ receptor (FceRI)-bearing cells in bronchial biopsies from atopic and nonatopic asthma. Am J Respir Crit Care Med 1996; 153: 1931-1937.

30 Huber M, Helgason CD, Damen JE, et al. The src homology 2-containing inositol phosphatase (SHIP) is the gatekeeper of mast cell degranulation. Proc Natl Acad Sci USA 1998; 95: 11330-11335.

31 Gilchrest H, Cheewatrakoolpong B, Billah M, et al. Human cord blood-derived mast cells synthesize and release I-309 in response to IgE. Life Sci 2003; 73: 2571-2581.

32 Corren J, Casale T, Deniz Y, et al. Omalizumab, a recombinant humanized anti-IgE antibody, reduces asthma-related emergency room visits and hospitalizations in patients with allergic asthma. J Allergy Clin Immunol 2003; 111: 87-90. 